\title{
MORPHOLOGICAL CHANGES IN THE SMALL INTESTINE OF RATS WITH ACUTE GENERALIZED
} PERITONITIS

\begin{abstract}
Summary. The main cause of mortality in acute generalized peritonitis (AGP) is the development of multiple organ insufficiency. The intestine is the organ where the first changes develop in this pathology.

The aim of the study - to research and evaluate the morphological changes in the small intestine wall of animals with experimental AGP.

Materials and Methods. 32 white rats were used in this study. Acute peritonitis was modeled by introduction of $10 \%$ fecal suspension in the dosage of $0.5 \mathrm{ml}$ per $100 \mathrm{~g}$ of the animal's weight into the abdominal cavity of rats by puncture. The terms of observation: the $1 \mathrm{st}, 3 \mathrm{rd}$ and the 7th days from the beginning of the peritonitis modeling. For histological study the intestinal tissue was taken. The resulting pieces of the organ were fixed in a $10 \%$ neutral formalin solution, which were then stained with hematoxylin and eosin. Results and Discussion. On the 3rd day of the experiment in animals with a modeled AGP, vascular changes were manifested first of all by the rounding (retraction) of endothelial cells or their desquamation and the appearance of defects, that allow plasma proteins and the formed elements of blood to leave circulation boundaries of the vascular bed. On the 7 th day in animals with a modeled AGP increased vascular permeability of the mucous membrane of the small intestine was accompanied by a significant edema of the stroma of the villi and by focal hemorrhages.

Conclusion. Consequently, the distinct inflammatory changes in all terms of the injury were seen in the wall of the small intestine at the simulated AGP. The significant expansion of the capillaries and venules against the background of inflammatory infiltration in the stroma of the glandular component of the small intestine was noted on the 1st day from the beginning of the experiment. An increase in the height of intestinal villus and a crypt with retraction and desquamation of endothelial cells in the wall of vessels, which caused platelet adhesion in the areas of destruction was observed on the 3rd day. The areas of focal necrosis of the superficial epithelium, which were accompanied by multiple hemorrhages per diapedesis in the perivascular space of the mucous membrane, were seen in the wall of the small intestine of animals with a simulated AGP on the 7th day.
\end{abstract}

Key words: acute generalized peritonitis; the wall of small intestine; morphological changes.

INTRODUCTION Acute generalized peritonitis (AGP) remains the most common cause of postoperative lethality in urgent surgery $[1,2,3]$. The high mortality rate of patients with abdominal pathology is due to the severity of the course, diagnosis and complications. In the pathogenesis of AGP the most important damaging factors include hypotension, hypoxia, anemia, disorders of water and electrolyte metabolism, systemic inflammatory reactions and other disorders that occur at the system level in response to injury $[4,5,6]$.

The main cause of mortality in AGP is the development of multiple organ insufficiency [7]. The intestine is the organ that first undergoes changes in this pathology. The conducted analysis of scientific literature data showed that there is a number of conflicting data and no complete information about the morphological changes of structural components of the wall of the small intestine at various terms of AGP [8, 9]. In the available literature, we did not find any messages that would fully explain the pathomorphological mechanisms that underlie the development of complications of AGP. Our research was dedicated to solve this problem.

The aim of the study - to research and evaluate the morphological changes in the small intestine wall of animals with experimental AGP.

MATERIALS AND METHODS 32 white rats were used in the experiment. They were divided into two groups: the first group - 24 animals with a simulated AGP; the control group consisted of 8 intact animals that were kept under standard vivarium conditions. The comparable groups of animals were representative of weight, sex, and age. This experimental study was carried out in compliance with the general rules and regulations of the European Convention for the Protection of Vertebrate Animals used for research and other scientific purposes (Strasbourg, 1986), the General Ethical Principles of Animal Experiments (Kyiv, 2001) and the Law of Ukraine "On the Protection of Animals from cruelty" (2006).

AGP was studied on the model proposed by V. A. Lazarenko and co-authors [10]. This model, based on etiological factors, clinical manifestations and phase transition, is close to a similar process in humans. Animals of the main AGP group were modeled by administering a $10 \%$ filtered fecal suspension into the abdominal cavity of the test rats at a dose of $0.5 \mathrm{ml}$ per $100 \mathrm{~g}$ of body weight. The fecal suspension was obtained by mixing isotonic solution and feces from the intestine of 2-3 intact animals, then it was filtered twice through a double layer of cheesecloth. The resulting suspension was delivered to the intact rat by puncture method no later than 20 minutes after preparation. The animals were held upright, caudal end up to avoid damage of the internal organs while delivering the fecal suspension into the abdominal cavity. Using the puncture method of the ventral wall in the center of the abdomen middle line, directing the end of the needle to the right and left subcostal area, right and left iliac areas, the same amount of fecal suspension was injected.

The control group consisted of intact animals, which were kept under standard vivarium conditions. The removal of the material for histological examination was carried out on the 1st, 3rd and 7th days after withdrawal of animals from the experiment by their decapitation under thiopental anesthesia.

The intestine tissue was taken for histological studies. The resulting pieces of the organ were fixed in a $10 \%$ neutral solution of formalin and Lilli fixator, followed by pouring in paraffin. Serial sections of 4-5 microns thick were prepared from the prepared paraffin blocks.

Resulting in Sannomiya microtome sections were stained with hematoxylin and eosin, by Heidenhain and for Shabadashem. The nature and depth of morphological changes 
were determined by using the Olimpus microscope and histological imaging system.

RESULTS AND DISCUSSION In the histological preparations of the small intestine of the control group of animals, the wall of the small intestine is represented by three membranes, the mucous and submucosal basis, muscle and serous. The mucous membrane consists of four layers epithelium, own muscle plates and submucosal basis. Epithelium of a mucous membrane is a single-layer cylinder. The own plate is formed by loose connective tissue, muscular - smooth myocytes. The relief of the mucous membrane is represented by circular folds, villi and crypts. The circular folds are represented by the germs of the mucous membrane together with the submucosal base (Fig. 1).

The villi are represented by the germs of the mucous membrane, which is based on the connective tissue of its own plate, in which there are single smooth muscle cells. The surface of the villa is covered by a cylindrical epithelium, which consists of three types of epithelial cells: columnar epithelial cells, goblet cells and intestinal endocrinocytes. Columnal epitheliocytes of villi make up the main part of the epithelial layer of villus. These are high cylindrical cells that contain villi on the apical surface.

Goblet cells and endocrinocytes singly scattered on the villus surface surrounded by columnar epithelial cells of the rim (Fig. 1). Crypts - tubular germs contain columnar cells with a rim, goblet cells and endocrinocytes, Panet cells, located in the groups near the bottom of the crypt (these are prismatic forms). There is a sufficient number of columnar epithelial cells without borders, which are located in the structure of villi and crypts, along with columnar epithelial cells.

The own plate of the mucous membrane of the small intestine is formed by a loose connective tissue, in which there are a lot of elastic and reticular fibers, gauze of hemoand lymphocapillaries. The accumulation of lymphocytes is formed here by single or grouped lymph nodes.

In the structure of animals' intestine, the attention was paid to the epithelial pad, blood and lymph capillaries, interstitial space, connective tissue cells.

The integrity of the epithelial pad of the mucous membrane of the small intestine was observed in animals with a simulated AGP on day 1 . But along with this, the

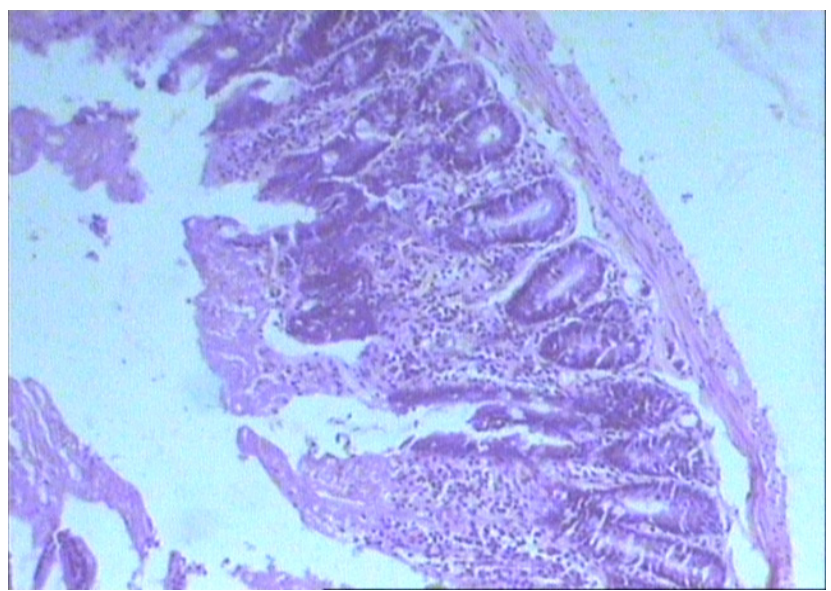

Fig. 1. Histological structure of the animal's intestine wall (control). Stained with hematoxylin and eosin. x200. number of goblet cells and intraepithelial lymphocytes was decreased (Fig. 2). In the own plate of the mucous membrane there were only tendencies to increase the number of macrophages and the number of mast cells.

In the intestinal wall, multiple vessels were found, with well-defined muscular wall and connected with the walls of the vessels located in different directions with the smooth muscle cells. In the stroma of the glandular component, inflammatory, mainly lymphoplasmocytic infiltration, was observed on separate areas with a significant number of eosinophilic leukocytes. The damage in the microcirculatory channel was characterized by the brightness of morphological changes. On the half-thin sections, there was a sharp plumage of the capillaries and venules, and sometimes "coin columns" from red blood cells were observed.

The process of platelet adhesion and aggregation are often correlated with morphological and functional changes and precipitation of fibrin on the surface, forming together the phenomenon of metamorphosis, so aggregation is irreversible.

In animals with a simulated AGP on day 3 of the experiment, vascular changes were first of all manifested by the retraction of endothelial cells or their desquamation and the appearance of defects, that allow plasma proteins and the formed elements of blood to leave circulation (Fig. 3). In turn, the gross damage of the endothelium caused a protective reaction - the adhesion of platelets in the areas of destruction. External vascular lesions were characterized by the release of the liquid part of the blood and of the separate formed elements in the perivascular space.

In the study of the enterocytes organization of intestinal villi and animal crypt there was noticed an increase in the height and number of epithelial cells and also the tendency to increase the volumetric density of intracellular organelles.

In animals with a simulated AGP on day 7 , the permeability of the vessels of the mucous membrane of the small intestine was increased and accompanied by a significant edema of the stroma of the villi and by focal hemorrhages (Fig. 4). The villi were shortened and expanded. At the same time, collumnar enterocytes suffered from dystrophic and non-fibrotic changes. In the cytoplasm, predominantly hyaline-drop and hydropic dystrophy were developed. It was completed by desquamation and bulging of the basement membrane with the development of multiple erosions.

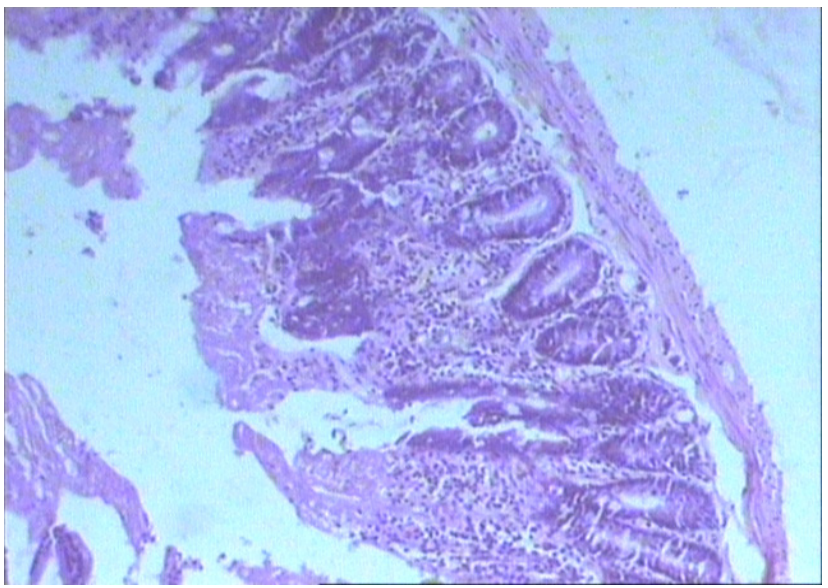

Fig. 2. Structure of the small intestine of animals with simulated AGP on the 1st day. Reducing the number of goblet cells and intraepithelial lymphocytes in crypts. Swelling of the mucous membrane. Stained with hematoxylin and eosin. x180. 


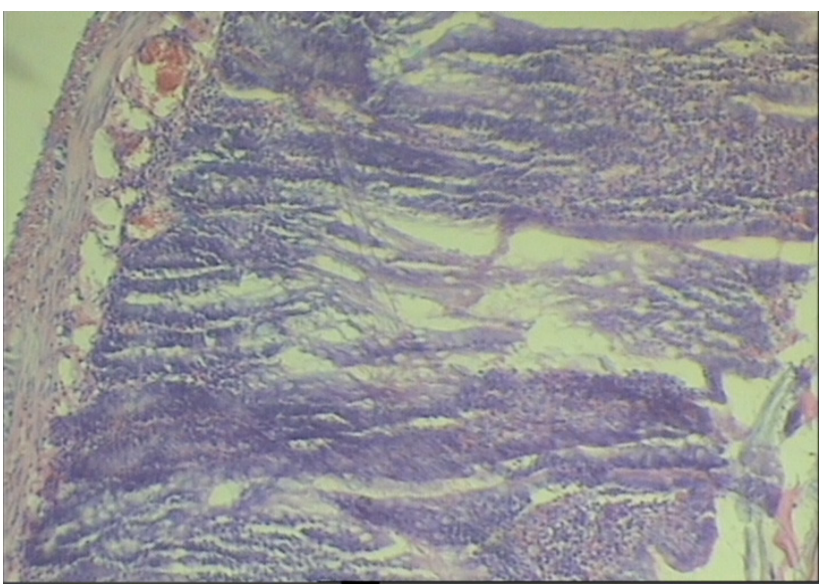

Fig. 3. The structure of the small intestine wall with a simulated AGP on the $3 r d$ day. Multiple hemorrhages per diapedesis in the perivascular space of the mucous membrane. Stained with hematoxylin and eosin. x180.

Hyperplasia of lymphoid tissue with accession of exudative inflammation with the predominance of neutrophils in the exudate was observed locally, in the mucous membrane. Similar changes were observed in the serous membrane, where also swelling and cellular infiltration were indicated.

The villi of the mucous membrane were expanded and shortened due to diffuse lympho-histiocytic stromal infiltration. The villi capillaries were expanded and caused multiple hemorrhages per diapedesis. There was a focal necrosis of the surface epithelium.

CONCLUSIONS Consequently, the pronounced inflammatory changes in all terms of the injury were seen in the wall of the small intestine at the simulated AGP. The significant congestion of the capillaries and venules was noted on the 1st day from the beginning of the experiment

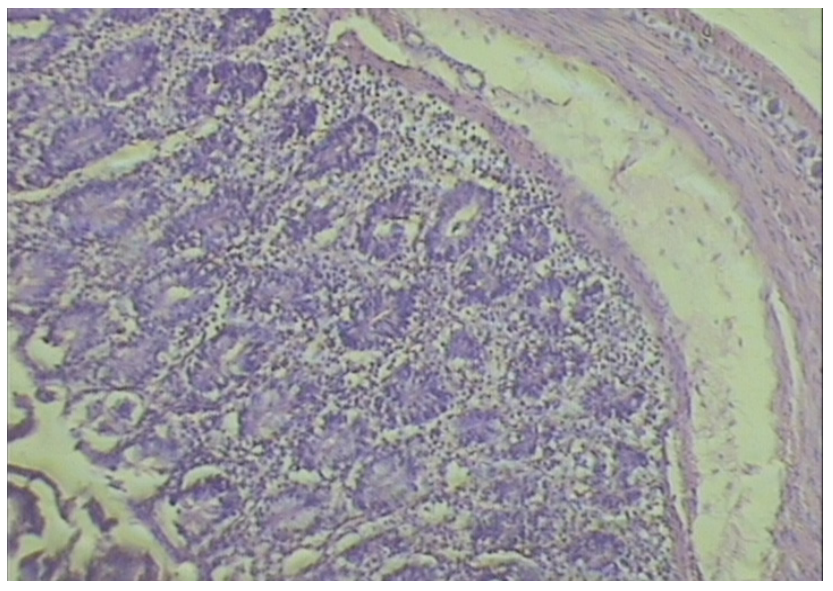

Fig. 4. The structure of the small intestine wall with a simulated AGP on the 7th day. Exudative inflammation with predominance of neutrophils in the exudate, edema. Stained with hematoxylin and eosin. x180.

against the background of inflammatory infiltration in the stroma of the glandular component of the small intestine. An increase in the height of intestinal villus and a crypt with a retraction and desquamation of endothelial cells in the wall of vessels, which caused platelet adhesion in the areas of destruction was observed on the 3rd day. The areas of focal necrosis of the superficial epithelium, which were accompanied by multiple hemorrhages per diapedesis, in the perivascular space of the mucous membrane, were seen in the wall of the small intestine of animals with a simulated AGP on the 7th day.

Prospects for further research The study and evaluation of morpho-functional changes of small intestine walls in rats with a simulated AGP will allow to broaden the idea of multiple organ failure mechanisms activation in this pathology.

\section{LIST OF LITERATURE}

1. The microbiology of postoperative peritonitis / A. Roehrborn, L. Thomas, O. Potreck [et al.] // Clin. Infect. Dis. - 2001. - Vol. 33, No. 9. - P. 1513-1519. doi.org/10.1086/323333

2. Risk factors for multidrug-resistant bacteria in patients with post-operative peritonitis requiring intensive care / P. Seguin, Y. Fédun, B. Laviolle [et al.] // J. Antimicrob. Chemother. - 2010. Vol. 65, No. 2. - P. 342-346. doi: 10.1093/jac/dkp439.

3. Baba Guru Prasad N. A study of acute peritonitis: evaluation of its mortality and morbidity / N. Baba Guru Prasad, K. V. Bhaskar Redd // International Surgery Journal. - 2016. - Vol. 3, No. 2. P. 663-668. doi: http://dx.doi.org/10.18203/2349-2902.isj20161140

4. Blood electrolytes changes in peritonitis of cattle / M. R. Mokhber Dezfouli, S. Lotfollahzadeh, S. Sadeghian [etal.]// Comp. Clin. Path. -2012. - Vol. 21, No. 6. - P. 1445-1449. doi: 10.1007/s00580-011-1312-6

5. Pathophysiologie der Peritonitis / K. Beyer, P. Menges, W. Keßler, C. -D. Heidecke // Der. Chirurg. - 2016 - Vol. 87, No. 1. - P 5-12. doi: 10.1007/s00104-015-0117-6.

6. Sydorchuk L. I. Acute experimental peritonitis: microecological indexes, species composition and population level of large intestine microbiota of experimental animals after 6 hours of initiation / L. I. Sydorchuk // Клінічна та експериментальна патологія. -2015. - № 3(53). - C. 127-132.

7. Дзюбановський І. Я. Синдром поліорганної недостатності та його корекція у хворих на гострий поширений перитоніт / І. Я. Дзюбановський, Б. О. Мігенько // Укр. журн. хірургії. - 2009. - № 2. - С. 56-59.

8. Лубянский В. Г. Основные патогенетические механизмы развития острых перфораций кишечника у больных с послеоперационным перитонитом / В. Г. Лубянский, А. Н. Жариков // Acta Biomedica Scientifica.- 2012. - № 4(1). - C. 51-55.

9. Ашрафов Р. А. Гистологические и гистохимические изменения тонкой кишки при перитоните / Р. А. Ашрафов, А. Э. Лычкова // Фундаментальные исследования. - 2012. № 4 (часть 1). - С. 22-24.

10. Экспериментальная модель распространенного калового перитонита / В. А. Лазаренко, В.А.Липатов, Ю. Ю. Блинков, Д. В. Скориков // Человек и его здоровье. - 2008. - № 4. С. $128-132$. 


\section{МОРФОЛОГІЧНІ ЗМІнИ В СТІНЦІ ТОНКОї КИШКИ ПРИ ГОСТРОМУ ПОШИРЕНОМУ ПЕРИТОНІТІ}

Резюме. Основною причиною смертності при гострому поширеному перитоніті (ГПП) є розвиток поліорганної недостатності. Кишечник - це орган, в якому розвиваються перші зміни при даній патології.

Мета дослідження - вивчити та оцінити морфологічні зміни в стінці тонкої кишки у тварин із експериментальним гострим поширеним перитонітом.

Матеріали і методи. У дослідженні використали 32 білих щурів. Гострий перитоніт моделювали шляхом введення 10 \% калової суспензії у дозі 0,5 мл на 100 г маси тварини у черевну порожнину експериментальних щурів пункційним методом. Терміни спостереження: 1; 3; 7 доби від початку моделювання перитоніту. Для гістологічних досліджень брали тканину кишечника. Отримані шматочки органа фріксували в 10 \% розчині нейтрального формаліну, який потім фрарбували гематоксиліном та еозином.

Результати досліджень та їх обговорення. У тварин із змодельованим ГПП на 3 добу експерименту судинні зміни перш за все проявлялись округленням або десквамацією ендотелію, появою десектів, що призводило до виходу плазми та формених елементів крові за межі судинного русла. У щурів із змодельованим ГПП на 7 добу підвищення проникності судин слизової оболонки тонкої кишки супроводжувалося значним набряком строми ворсинок та осередковими геморагіями.

Висновки. Виражені запальні зміни у стінці тонкої кишки при змодельованому ГпП були на усіх термінах ураження. На першу добу від початку експерименту на тлі запальної інфрільтрації у стромі залозистого компонента тонкої кишки відзначалося значне розширення капілярів і венул. На 3 добу спостерігалося збільшення висоти кишкових ворсинок і крипт із вираженою десквамацією ендотелію у стінці судин, що викликало адгезію тромбоцитів у зонах ураження. На 7 добу в стінці тонкої кишки тварин із змодельованим ГПП були ділянки фокального некрозу поверхневого епітелію, які супроводжувалися множинними діапедезними крововиливами в периваскулярний простір слизової оболонки.

Ключові слова: гострий поширений перитоніт; стінка тонкої кишки; морфологічні зміни.

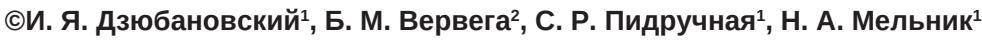

Тернопольский национальный медицинский университет имени И. Я. Горбачевского ${ }^{1}$ Львовский национальный медицинский университет имени Данила Галицкого 2

\section{МОРФОЛОГИЧЕСКИЕ ИЗМЕНЕНИЯ В СТЕНКЕ ТОНКОЙ КИШКИ ПРИ ОСТРОМ РАСПРОСТРАНЁННОМ ПЕРИТОНИТЕ}

Резюме. Основной причиной смертности при остром распространенном перитоните (ОРП) является развитие полиорганной недостаточности. Кишечник - это орган, в котором развиваются первые изменения при данной патологии.

Цель исследования - изучить и оценить морфологические изменения в стенке тонкой кишки животных с экспериментальным острым распространенным перитонитом.

Материалы и методы. В исследовании использовали 32 белых крыс. Острый перитонит моделировали путем введения $10 \%$ каловой взвеси в дозе 0,5 мл на 100 г массы животного в брюшную полость экспериментальных крыс пункционным методом. Сроки наблюдения: 1; 3; 7 сутки от начала моделирования перитонита. Для гистологических исследований брали ткань кишечника. Полученные кусочки органа фриксировали в 10 \% растворе нейтрального фрормалина, который затем окрашивали гематоксилином и эозином.

Результаты исследований и их обсуждение. У животных при смоделированном ОРП на 3 сутки эксперимента сосудистые изменения в первую очередь проявлялись округлением или десквамацией эндотелия, появлением дефектов, что приводило к выходу плазмы и форменных элементов крови за пределы сосудистого русла. У крыс при смоделированном ОРП на 7 сутки повышение проницаемости сосудов слизистой оболочки тонкой кишки сопровождалось значительным отеком стромы ворсинок и очаговыми геморрагиями.

Выводы. Выраженные воспалительные изменения в стенке тонкой кишки при смоделированном ОРП были на всех сроках поражения. На первые сутки от начала эксперимента на фоне воспалительной инорильтрации в строме железистого компонента тонкой кишки отмечалось значительное расширение капилляров и венул. На 3 сутки наблюдалось увеличение высоты кишечных ворсинок и крипт с выраженной десквамацией эндотелиальных клеток в стенке сосудов, что вызвало адгезию тромбоцитов в зонах поражения. На 7 сутки в стенке тонкой кишки животных с моделируемым ОРП наблюдались участки фокального некроза поверхностного эпителия, которые сопровождались множественными диапедезными кровоизлияниями в периваскулярное пространство слизистой оболочки.

Ключевые слова: острый распространенный перитонит; стенка тонкой кишки; морфологические изменения.

Address for correspondence: B. M. Verveha, Danylo Halytskyi Lviv National Medical University, Pekarska street, 69, Lviv, 79000, Ukraine, e-mail: danaverveha@gmail.com 